\title{
UNDERVALUED OR MISUNDERSTOOD? YOUTH WORK AND ITS CONTRIBUTION TO LIFELONG LEARNING
}

\author{
Ken Harland \\ School of Sociology and Applied Social Studies, \\ University of Ulster, Northern Ireland

\section{Tony Morgan} \\ School of Sociology and Applied Social Studies, \\ University of Ulster, Northern Ireland
}

\begin{abstract}
This paper discusses the relevance of informal educational experiences associated with youth work practice in Northern Ireland. It argues that youth work is distinctly educational and involves constructive interventions with young people and that its role and contribution are often undervalued or misunderstood. Youth work plays a vital role in supporting young people through the increasingly prolonged and complex transition from youth to adulthood. While youth work sits within a theoretical framework of informal education, its contribution to lifelong learning is perhaps of greater significance than has previously been recognized.
\end{abstract}

\section{The Nature and Purpose of Youth Work}

The roots of youth work as a method of informal education have their origins in the mid-19th century (Milburn et al., 2003). While it is difficult to say exactly when the term youth work became prevalent, the Young Men's Christian Association (YMCA), set up in 1844, has been identified as the first dedicated youth organization (Smith, 2002). Other significant factors in the emergence of youth work were increasing public interest in youth as a distinct category with specific needs and a more scientific theorizing of the term adolescence by psychologists such as Hall (1904).

Despite its history, the concept of youth work can be difficult to define and therefore has produced competing views as to its fundamental purposes and nature (Tucker, 1994; Harland, Morgan, \& Muldoon, 2005). While Smith (1988, p.51) argues that it is helpful to think of there being "different forms of youth work rather than a single youth work with commonly agreed characteristics," Jeffs and Smith (1999, p.48, 2010, p.3) identify several distinctive characteristics that have been present to differing degrees in youth work practice since the early 1900's:

- Youth work is directed towards young people.

- Youth work has an educational purpose.

- Youth work is a commitment to association--joining together in companionship to undertake some task, and the educative power of playing one's part in a group or association. 
- The personality or character of the worker is of fundamental importance.

- The relationship between a youth worker and a young person is voluntary.

It is worth mentioning that the concept of youth is problematic when deciding on intervention. For example, the youth service in Northern Ireland is charged with young people between the age of 4 and 25. Agreeing on what constitutes youth is an important part of the current discussion in Northern Ireland in terms of what should be offered by the youth service. Some practitioners have suggested that those under 10 should be offered play work, and that only those between ages 12 and 18 should be dealt with by youth service. The main point is that although youth workers categorically work with young people, there is no agreed definition of the concept of youth.

\section{Underlying Youth Work Principles}

Jeffs (2001) has commented that it is the voluntary principle that has distinguished youth work from most other services to youth people. Participation and group association is not compulsory, and therefore, a young person retains the right to freely enter into relationships with youth workers and other young people and to end these relationships when they choose. This contrasts with problem-based interventions and deficit models which have been so dominant within social policy directed at young people (Davis, 2005). Increasingly deficit models have orientated youth work towards supporting vulnerable, excluded, or at-risk young people in negotiating more successful youth to adult transitions (Mizen, 2003; Jeffs \& Smith, 2006; Spence, 2007). This is an important consideration as youth to adult transitions have become more prolonged and complex and characterized by greater risk and uncertainty (Shildrick \& MacDonald, 2007).

Smith (1982, p.24) states that youth work is the "conscious attempt to help young people gain for themselves, the knowledge, feelings, and skills necessary to meet their own and others developmental needs." Williamson (1995) argues that there is a developmental process in all youth work practice, beginning with a focus on the individual, developing into group formation, consolidation, and growth. This is reinforced by Spence, Devanney, \& Noonan (2006) who assert that youth work processes begin with informal, person-centered approaches that develop into planned structured interventions as a means to achieve predetermined outcomes. Research has shown that young people on youth work programs learn more effectively in settings where they feel safe, valued, supported, and involved in decisionmaking processes about issues that affect their lives (Harland, 2001; Harland, Morgan, \& Muldoon, 2005).

Young (1999, p.61) states the view that"youth work engages young people in the process of moral philosophizing as a function of their identity development and responsibility as social beings in a social world." She further asserts that the 
uniqueness of youth work is not found in its methods, curriculum content, or targets groups, but through its ability to support and enable young people to explore fundamental questions about their own identity—principles that are also present in much of the literature around lifelong learning.

Like formal education, youth work is essentially part of a lifelong learning educational process (Youth Work: A Model for Effective Practice, 2003). One key difference, however, is that youth work occurs in nonformal settings as opposed to formal structures within schools, colleges, and universities. The notion of the learning environment is given serious consideration within youth work. Mahoney (2005) suggests that youth workers can be identified as informal educators through the unique way in which they engage in the daily lives of young people in a range of informal settings. Mahoney argues that being conscious about how and where youth workers engage young people, contributes to the development of youth work practice.Youth workers seek to work in ways which encourage young people to use their experiences of everyday living as opportunities for learning about themselves and others (Crosby, 2005, p.54). Spence et al. (2006) state that youth work practice is inextricably linked to the realities of young peoples' lives and is affected by local culture and the relationships that young people have with other people and institutions such as the family, school, and police. These authors state that "these realities are given conceptual cohesion in the language of informal education, which encapsulates both the informal, relational aspects of the work and its intentions towards constructive learning and development" (Spence et al., 2006, p.134). Importantly, however, these authors argue that while youth work sits within the theoretical framework of informal education, the language of youth work has not been fully developed.

\section{Youth Service in Northern Ireland}

The social and political troubles, which began in 1969, significantly altered the shape and direction of youth work in Northern Ireland. In the early 1970s youth workers were increasingly employed to deliver diversionary programs aimed at keeping young people, particularly young men, off the streets and away from violence. Subsequently youth work in Northern Ireland took a different direction from youth work in the rest of the UK and Ireland. In 1973, as part of local Government reorganization, Education and Library Boards were established that were responsible for the statutory provision of youth services in Northern Ireland.

The Youth Service (NI) Order 1989, which succeeded the Recreation and Youth Service (NI) Order 1973 and the Education and Libraries (Northern Ireland) Order 1986 Article 37, stated that youth service could be provided either directly by Education Boards themselves or through assisting, both financially and nonfinancially, other youth service providers in the organization of activities. This evolved into the creation of three distinct statutory, voluntary, and community youth sectors. The statutory sector consists of youth clubs, area projects, and residential centres. The voluntary and community sectors are made up of a greater variety of community 
groups, organizations, including church based, uniformed, headquarter, and umbrella groups. Since the late 1960s youth work has also been significantly shaped by the fact that young people have grown up in a deeply divided and contested society. Sectarianism and the effects of the social and political troubles have been shown to have a significant influence upon young people growing up in Northern Ireland (Bell, 1990; Harland, Morgan, \& Muldoon, 2005). Connolly and Maginn (1999, p.97) found that sectarianism amongst children in Northern Ireland was rooted in their day-to-day experiences, and by the age of three, children had not only developed an understanding of the categories of "Protestant" and "Catholic," but were able to apply negative characteristics each to the other.

The Youth Service in Northern Ireland encompasses a broad diversity of provision that includes services for children less than 10 years of age, services for young people aged 10-16 years old, and services to young adults. The Northern Ireland Strategy for Youth Work 2005-2008 states its vision is to promote the development, well-being, rights, and participation of young people by ensuring all young people in Northern Ireland the following:

- They are able to enjoy themselves, realise their potential, and participate as active citizens in a secure and peaceful society.

- They know their rights and responsibilities and have these rights protected and promoted.

- They feel valued, understood, and feel safe and supported.

In order to understand the underpinning philosophical and ideological concepts of youth work in Northern Ireland, it is important to take cognisance of the core principles of the Department of Education (2003, p.11) permeating youth work: "a commitment to preparing young people for participation, the promotion of acceptance and understanding of others, and testing values and beliefs." These affirm the personal and social development of young people and ideally should be reflected in all youth work.

Northern Ireland is a society emerging from a period of prolonged violence, and reflection on any aspect of life must be considered in the context of the conflict that has been prevalent since 1969. Contemporary youth work takes place within the context of "a legacy of violence and communal strife, alongside other issues that affect modern society" (Department of Education, 2003, p.16). Providing support to young people, often at the forefront of community and sectarian violence, has been a major aspect of youth work practice in Northern Ireland for over three decades (Harland, Morgan, \& Muldoon, 2005).

One of the most powerful influences in encouraging young people in a contested and divided society is to engage in reconciliation work. Youth workers have potential to be valuable role models and by their example can encourage acceptance and understanding of others, which are an important aspect of youth work curricu- 
lum seen within broader principles of equity, diversity, and interdependence. These principles promote appreciation of the difference between, and interdependence of, people within society, and builds upon community relations practice developed in response to the Northern Ireland conflict since 1969.

\section{Youth Work and Employment.}

Youth work has a role in the development of social capital while increasingly being drawn into the debate about human and economic capital. One of the challenges for youth work has, and will continue to be, the role played in training for employment. The transition from school presupposes the belief that school has prepared young people for the world of work or indeed civic society. Pohl and Walther (2007) refer to a process of activation, i.e., the transition of disadvantaged young people from school to work, by asking the following question:" [If it is] possible to specify whether activation implies adaptation to mechanisms of selection in education, training and the labour market, or whether it increases young people's potential to take action in shaping their own biographies (i.e. through participation and lifelong learning)."(p.533)

While policies driven by education, training, and the needs of the labor market are extremely influential they often miss those young people on the margins of society. Shildrick and MacDonald (2007, p.591) state that the most damaging problem with the "transition debate" is that it has tended to take young people out of the youth equation by treating young people as troubled victims of economic and social restructuring without enough recourse to the active ways in which young people negotiate such circumstances in the course of their everyday lives.

This is a sentiment and goal that youth work practice attempts to redress. In Northern Ireland youth work programs are designed in response to the issues that young people consider important. Examples of this include informal education programs focusing on sexual health, sexuality, mental health, violence, community relations, anti-social behaviour, drug and alcohol awareness, sport, peer education, leadership (Harland, Morgan, \& Muldoon, 2005). Youth work occurs in many informal settings ranging from youth centers, community centers, schools, street work, churches, residential centers, and hired accommodation. Crucially, however, these environments are secondary to the nature and purpose of youth work. Conversations between youth workers and young people can occur anywhere. It is this informal aspect of youth work that has been misunderstood or undervalued in analysis of lifelong learning. In particular the role that youth work plays in rebalancing the lives of marginalised young people towards more realistic, rather than idealistic youth to adult transitions (Morgan et al, 2000).

\section{The Role of Youth Work}

In Northern Ireland youth workers increasingly find themselves attempting to redress the disadvantage experienced by young people due to extraneous factors such 
as low academic achievement, peer pressure, drug use, alcohol abuse, trends in mental health and suicide, relationships, community expectations, racism, violence, sexuality, ethnicity, sectarianism, religion, and antisocial behaviour. Shildrick and MacDonald (2007, p.589) suggest that the linear movement from youth to adult, focuses narrowly on educational and employment, prioritizes normative and policy-focused assumptions, and often de-prioritises the actual lived experiences of young people.

Many youth workers would agree with Shildrick and MacDonald's sentiments because they work alongside young people as they navigate themselves through a complex set of societal domains. Youth workers have had to become a sort of "community entrepreneur" in terms of redirecting time and resources to redress these complex issues in young people's lives. This has also had a considerable impact on shaping the delivery of youth work, particularly with marginalized young people.

A study by Harland et al. (2005) found that youth workers had difficulty articulating outcomes from their practice. Many illustrated their understanding of youth work as a process rather than a product. Youth workers spoke of outcomes in terms of raising self-esteem, building confidence, and challenging negative attitudes-what they termed "bite-size" results. While these are important outcomes, youth workers struggled to demonstrate outcomes more grounded in a language associated with current policy demands. In addition they were concerned that youth work was moving away from its historical and core objectives in order to meet the demands and language of ever changing funding bodies and government youth policies. This has been particularly evident in Northern Ireland throughout the peace process as European Peace and Reconciliation funding mechanisms have increasingly demanded more robust outcomes as an expression of value for money.

Measurement of tangible outcomes through the concept of capital is a move towards meaningful understanding in this regard. In Social Capital: Key Ideas (2003), Field describes the theory of social capital as "at heart, most straightforward--its central thesis can be summed up in two words: relationships matter." Field says that maintaining these relationships over time individuals can achieve more than they would have expected if they did not have this strong relationship. If we agree that youth work offers young people, particularly marginalized young people, social capital in the form of relationships and support, then the movement of this form of capital into useful, human/economic capital could be useful as a vehicle for moving youth to adulthood. However, there are acute differences in regard to how formal and informal education supports young people through this transitional phase of their lives. "The young and disadvantaged now face a series of revolving doors, unstable, non-progressive youth transitions in which chronologically arranged government labor market programmes are central components." (Shildrick \& MacDonald 2007, p.597) Pohl and Walther (2007, p.535) discuss"yo-yo"transitions in which young people experience aspects of youth and adulthood simultaneously and feel stuck somewhere in between. 
Youth work, if it is to continue as an informal educational activity outside the formal system (schools and higher education) may, according to Field (2002), have to start using the language of markets and competition. He says that if this is the case, then there may be negative unintended consequences:" output-related funding, rather than improving performances of service-delivery agencies such as colleges, youth service (authors'italics), has often distorted their behavior." (p.209)

Field (2002, p.210) warns that the fuzzy nature of soft outcomes will create problems if they are used by Government to achieve certain political objectives. Field adds, however, that it is unlikely ministers or civil servants will feel confident in their capacity to develop clear criteria for judging success or failure. This is important to youth work in that many of its outcomes are perceived as soft and by nature difficult to quantify. Governments fund programs that can offer transparency, measurable outcomes and quantifiable outputs. Field says that governments will only offer small amounts of finance partly because of the difficulties they face in establishing whether the results offer value for money. For Field (2002, p.211) intangible factors invariably present policy makers with measurement problems. He says that pursuing soft objectives through partnerships with nongovernmental actors also lays government open to the charge of throwing money away.

Field and Schuller (2002, p.86) discuss the pursuit and development of adequate measures for assessing the accumulation or erosion of social capital. They suggest that rather than think of alternatives or competing sets of measures, a concept of nested sets may be useful:" from the narrowest qualifications-focused to the broadest set of social indicators, each fulfilling different roles." (p.86) They acknowledge the importance of both social and human capital which at times may mean"a trade-off between specificity and focus on the one hand, and contextualisation and scope on the other." (p.86) They argue that building such a nested structure should help avoid, "the quantitative spuriousness of the human capital approach on the one hand and the over-inclusive vagueness of social capital on the other." (p.86)

Irrespective of the rationale for funding programs that offer soft outcomes, Field and Schuller (1998) suggest that there is a correlation between social capital and participation in lifelong learning and a direct relationship between future study and low educational achievement. Indeed Field (2003b) goes much further when he suggests that most people in Northern Ireland think that their school did not help them prepare for learning in adult life. When asked specifically if school taught them the skills and knowledge they needed later in life, 70\% of women and 71\% of men said no. Asked if school opened people's minds and made them want to learn, $74 \%$ of women and $79 \%$ of men said no. Field's conclusions appear to be positive for those that avail of it in terms of the contribution that education can make to people's lives. In Northern Ireland the standards at "A"levels are exceptionally high as is, interestingly, the percentage of young people leaving school with no qualifications. Paradoxically, many people are not convinced that school provides an adequate preparation for learning in adult life (Harland, 2000; Field, 2003). 


\section{The Contribution of Youth Work to Lifelong Learning}

Whereas formal education focuses primarily on qualifications (product driven human capital), youth work focuses heavily on personal and social issues (process driven social capital). The informal nature of youth work also enables youth workers to address many issues with young people that are not covered within a formal educational curriculum. Undoubtedly this position conflicts with the types of hard outcomes that are identifiable in higher education. However, there should be greater recognition of the potential for youth work to complement formal education and underpin personal development and the acquisition of social skills and knowledge among young people.

No single profession or discipline can claim to meet all the needs of young people in any society, and there are many potential benefits to young people through professional collaboration and multidisciplinary approaches. Youth work supports and encourages a young person to pursue personal interests and address their everyday lived experiences. In contrast formal education operates within a much more structured and less flexible curriculum. This is perhaps where opportunity and creativity for links between formal education and informal youth work best lie.

One possible starting point for developing links between formal and informal education has been identified by (Morgan et al., 2007). This research examined the role of youth work in schools supporting disengaged young people. One finding was that youth work principles were somewhat incongruent in the formal school setting, and on occasions youth workers believed that they had to compromise key youth work principles. For example, the emphasis on relationship building within youth work was not always fully understood by teachers. Other more latent principles underpinning youth work also conflicted, that is, the voluntary nature of the relationship between young people and adults, flexibility with learning due to the lack of a prescribed curriculum, and an emphasis on personal development. Dress code, time tables, and young people's form of address for adults were also identified as difficult areas for youth workers and teachers to agree upon. This study noted many benefits and opportunities of schools employing youth workers to work with disaffected or disruptive young people. It also acknowledged that when youth workers moved outside their learning environments, it was more difficult for them to deliver what they considered "real youth work." Youth work will need to take cognizance of a school ideology and what a school expects from a pupil. There are many opportunities for new thinking and creativity in the development of strategies that can combine formal and informal approaches in order to meet the educational needs of young people that link school, work, and lifelong learning. Youth workers are undoubtedly skilled in working with young people who may not comply with expected norms. Loughlin et al. (2005) outline a multidisciplinary approach within education that draws upon the skills and knowledge of youth workers. Morgan et al. (2007) argue that initial teacher training should incorporate youth work processes in order to enhance the widest educational experience of new teachers. 
While more research is needed in this area, there is no doubt that there could be many benefits from developing a broader educational framework for working with disengaged young people in schools.

This paper proposes that there are many untapped opportunities for combining formal and informal educational approaches. This may necessitate a change in how education and learning are perceived and how it is linked to human capital with little cognizance taken of the personal developmental aspect of social capital for marginalized youth. What is needed, says Goodwin and O'Connor (2007, p.570) is more creative thinking that does not seek answers in past patterns of transitions between youth to adulthood that relate only to an economic imperative. They also observe,"Although in the past the outcomes of transitions were seen as largely predictable...it is possible that the young workers subjective experiences were neither predictable, uniform, nor unproblematic." (p.570)

This sentiment suggests three things. a) Youth work needs to continue to work closely with young people to find answers to complex social issues. b) Looking for answers in the past may have limited value. c) We cannot ignore how important it is for young adults to be engaged in a process of switching them "on" and not "off" to lifelong learning. Stokes and Wyn (2007) claim that"forcing normative patterns to become universal would automatically ensure universal success, seriously hampers the development of educational processes that could more effectively support young people by facilitating flexible education-work trajectories." (p.499)

Young people need assistance to navigate the complex social world of work and survival through projects that address the need for building knowledge, skills, understanding, and subsequent resilience to cope with the compounded difficulties of marginalization. Stokes and Wyn (2007) take this a step further by suggesting that school should be shaped to facilitate the employment needs of young people while they are still in education because they recognise the importance of work-based learning for future careers. This provides opportunities to work with young people, particularly young people who may be struggling academically, in more creative and realistic ways that better meet their vocational aspirations.

Educationalists may not be ready for concepts such as linking part-time work with the school curriculum even though both engage young people simultaneously. Stokes and Wyn (2007, p.508) argue that adult and youth practices often blur the boundaries of youth, adult, student, and worker. There is no doubt that young people involved in part-time work appear to understand learning within this context, primarily as a means of preparing for, and securing advantage, within the labor market as well as financial gain (Brooks, 2006, p.287). In a rapidly changing world, new and more creative thinking is needed, in regard to how educationalists meet the diverse needs of young people. Part of this creativity must lie in the establishment of more effective partnerships between those whose primary responsibility is the development and education of young people, that is, youth work, schools, and training. This necessitates a holistic approach 
to learning and recognition that no one profession has the capacity to meet the needs of all young people.

\section{Concluding Comments}

At the heart of youth work is the unique relationship between youth workers and young people. Youth work is a distinctly educational process and involves constructive interventions with young people. Its delivery is inclusive and holistic, and facilitates the personal, social, and educational development of young people leading ultimately to adulthood and employment.

Crucially, however, young people's abilities and contribution to society continue to be measured primarily through their experience of formal education. Those who focus on human capital related learning often fail to recognise and appreciate the diverse talents and skills of young people who are not necessarily academic but nevertheless of extreme importance. The fact that youth work places enormous value on social capital, through relationship building, is perhaps a key reason why it does not have the credibility within formal education. Professions such as social work, probation, youth justice, and schools are increasingly seeking the skills and knowledge of youth workers and recognizing how youth work's holistic approach complements and enhances other educational interventions that aim to re-engage marginalized young people.

Despite its history, youth work appears to be undervalued and misunderstood in a wider educational context. This may be in part due to youth work's primary focus on person centered relationships which contrast and conflicts with the problem centered focus of many youth policies. Other contributory factors include youth work's underdeveloped language within a theoretical framework of informal education and the fact that outcomes cannot always be predetermined. These are some of the fundamental reasons that have contributed to youth work being undervalued and misunderstood. They may also be instrumental in determining why youth work has, to date, been conspicuously absent from critical debate within lifelong learning literature.

\section{References}

Banks, S. (2005). Professional values in informal education work. In L.D. Richardson, \& M. Wolfe, (Eds.), Principles and practice of informal education: Learning through life. New York: Routledge.

Bell, D. (1990). Acts of union: Youth culture and sectarianism in Northern Ireland. London: Palgrave Macmillan.

Brooks, R. (2006). Learning and work in lives of young people. International Journal of Lifelong Learning, 25. 271-289. 
Connolly, P., \& Maginn, P. (1999). Sectarianism, children, and community relations in Northern Ireland. University of Ulster, Centre for the Study of Conflict.

Crosby, M. (2005). Working with people as an informal educator. In. L.D. Richardson, \& M. Wolfe, (Eds.), Principles and practice of informal education: Learning through life. New York: Routledge.

Davis, B. (2005). Youth work: A manifesto for our times. Youth \& Policy, 88, 5-28.

Department of Education. (2003). Youth work: A model for effective practice. Update 2003. Department for Education, Northern Ireland.

Doyle, M.E. (2005). On being an educator. In L.D. Richardson, \& M. Wolfe, (Eds.), Principles and practice of informal education: Learning through life. New York: Routledge.

Field J. (2002). Governing the ungovernable: Why lifelong learning policies promise so much yet deliver so little. In R. Edwards, N. Miller, N. Small, \& A. Tait, (Eds.), Supporting lifelong learning. Reader for E845 open university module. London and New York: Routledge.

Field, J. (2003). Social capital: Key ideas. London and New York: Routledge, Taylor and Francis Group.

Field, J. (2003b). Research update for AR. Social and Political Archive. Northern Ireland, 17: February.

Field, J. \& Schuller T. (1998). "Social capital, human capital and the learning society." International Journal of Lifelong Education, 17(4) 226-235.

Field, J. \& Schuller, T. (2002). Social capital, human capital and the learning society. In R. Edwards, N. Miller, N. Small, \& A. Tait, (Eds.), Supporting lifelong learning. Reader for E845 open university module. London and New York: Routledge.

Freire, P. (1970). Pedagogy of the oppressed. Harmondsworth: Penguin.

Goodwin, J. \& O'Connor, H. (2007). Continuity and change in the experiences of transition from school to work. International Journal of Lifelong Learning, 26(5) $555-572$. 
Hall, S. (1904). Adolescence: Its psychology and its relationship to physiology, anthropology, sociology, sex, crime, religion and education. (1), Englewood Cliffs:, N.J.: Prentice Hall.

Harland, K. (2000). Men and masculinity: An ethnographic study into the construction of masculine identities in inner city Belfast. Young men talking - voices from Belfast. Working with Men, (London:YouthAction Northern Ireland Publications). PhD submitted to the University of Ulster.

Harland, K. (2001). The challenges and potential of developing a more effective youth work curriculum with young men. Journal of Child Care in Practice, 7(4).

Harland, K. (2007). The legacy of conflict in Northern Ireland: Paramilitarism, violence and youth work in contested spaces. In D.Magnuson, \& M. Baizerman, (Eds.), Work with youth in divided and contested societies. Rotterdam: Sense Publisher.

Harland, K., Harvey, C., Morgan, T. \& McCready, S. (2005). Worth their weight in gold: The views of community youth work graduates in Northern Ireland on their chosen career. Youth \& Policy: Journal of Critical Analysis, 86.

Harland, K., Morgan, T. \& Muldoon, O. (2005). The nature of youth work in Northern Ireland: Purpose, contribution and challenges. University of Ulster and Queens University Belfast Publications.

Jeffs, T. (2001). Something to give and something to learn. In R. Gilchrist, \& T. Jeffs, (Eds.), Settlements, social change and community action. London: Jessica Kingsley.

Jeffs, T. (2004). Curriculum debate: A letter to Jon Ord. Youth \& Policy: Journal of Critical Analysis, 84.

Jeffs, T., \& Smith, M. (2006). Where is youth matters taking us? Youth \& Policy, 91, 23-40.

Jeffs, T., \& Smith, M. (2010). (Eds.). Youth work practice. London: Pelgrave McMillan.

Loughlin, F., McCartney, J., Morgan, P., \& Sherry, A. (2005). Why youth work in schools. In M. Glazewski, \& L. Salacinski, (Eds.), Conflicts, mediation and youth. Krakow: Poland.

Mahoney, J. (2005). What is informal education? In L.D. Richardson, \& M. Wolfe, (Eds.), Principles and practice of informal education: Learning through life. New York: Rutledge. 
Millburn, T. (2000). Connecting with young people and youth issues. Youth and Policy, 68.

Milburn, T., Rowlands, C., Stephen, S., Woodhouse, H., \& Sneider, A. (2003). Set it up: Charting young people's progress. University of Strathclyde.

Mizen (2003). Tomorrow's future of signs of a misspent youth? Youth policy and the first Blair government. Youth \& Policy, 79, 1-18.

Morgan, T., O'Hare, B., \& Campbell, H. (2000). The excluded adolescent: An exploration of the issues surrounding marginalised young people in Northern Ireland. A report for YouthNet. N. Ireland.

Morgan, T., Morgan, P., \& O'Kelly, B. (2007). Youth work in schools: An investigation of youth work, as a process of informal learning, in formal settings. Commissioned by the Department of Education for Northern Ireland. Final document June 2007.

Muldoon, O., Schmid, K., Downes, C., Kremer, J., \& Trew, K. (2008). The Legacy of the troubles: Experiences of the troubles, mental health and social attitudes. Retrieved February 8, 2008 from http://www.legacyofthetroubles.qub.ac.uk/LegacyOfTheTroublesFinalReport.pdf

Ord, J. (2004). The youth work curriculum and the transforming youth work agenda. Youth \& Policy, 83.

Pohl, A., \& Walther, A. (2007). Activating the disadvantaged.Variations in addressing youth transitions across Europe. International Journal of Lifelong Learning, 26(5), 533-553.

Shildrick, T., \& MacDonald, R. (2007). Biographies of exclusion: Poor work and poor transitions. International Journal of Lifelong Learning, 26(5), 589-604.

Smith, M. (1982). Informal education - conversation, democracy and learning. Derbyshire: Education Now Publications.

Smith, M. (1988). Developing youth work: Informal education, mutual aid and popular practice, Milton Keynes: Open University Press.

Smith, M. (1999). Praxis. An introduction to the idea. Retrieved from wwww.infed. org.uk 
Smith, M. K. (2002). Youth work: an introduction, The Encyclopedia of Informal Education. Retrieved on October 20, 2007 from www.infed.org/youthwork/byw.htm

Spence, J., Devanney, C., \& Noonan, K. (2006). Youth work: Voices of practice. Leicester: The National Youth Agency.

Spence, J. (2007). Support: In M. Robb (Ed.), Youth in context: Frameworks, settings and encounters. Sage: London.

Stokes, H., \& Wyn, J. (2007). Constructing identities and making careers: Young people's perspectives on work and learning. International Journal of Lifelong Learning, 26(5) 495-511.

Tucker, S. (1994). Changing times, changing roles? An examination of contemporary youth and community practice. Youth \& Policy, 46, 5-16.

Williamson, C. (1995). The dropout society: Young people on the margin. Leicester: The NationalYouth Agency.

Young, K. (1999). The art of youth work. Lyme Regis: Russell House Publications.

Youth work: A model for effective practice. (1997). Department of Education for Northern Ireland.

Youth work: A model for effective practice. (2003). Update by theYCNI for the Department of Education for Northern Ireland. 